\title{
SABANEJE WIA AURATA (DE FILIPPI, 1863) POPULATIONS MANAGEMENT DECISIONS SUPPORT SYSTEM FOR ROSCI0132 (OLT RIVER BASIN)
}

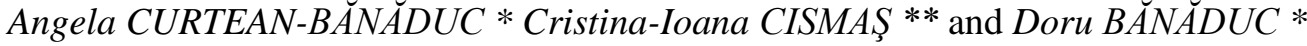 \\ * "Lucian Blaga” University of Sibiu, Applied Ecology Research Center, Dr. Ion Raţiu Street 5-7, Sibiu, \\ Sibiu County, Romania, RO-550012, angela.banaduc@ulbsibiu.ro, ad.banaduc@yahoo.com \\ ** "Lucian Blaga" University of Sibiu, Faculty of Sciences, Dr. Ion Raţiu Street 5-7, Sibiu, Sibiu \\ County, Romania, RO-550012, cristha_83@yahoo.com
}

DOI: 10.1515/trser-2015-0056

KEYWORDS: golden spined loach, Natura 2000 site, management, Romania.

\section{ABSTRACT}

The ADONIS: CE was used to design a specific management model for the Sabanejewia aurata (De Filippi, 1863) populations. The proposed model is based on this species, in situ identified biological/ecological necessities in relation to the habitats, the conservation status indicators and appropriate management actions and the pressures and threats founded in the study area. Such on species, on habitats and on site based management system was done to complete this approach for ROSCI0132, the other fish species which are living there being treated already in this respect.

ZUSAMMENFASSUNG: Ein unterstützendes Entscheidungssystem für das Management der Populationen von Sabanejewia aurata (De Filippi, 1863) im Natura 2000 Gebiet ROSCI0132 (Einzugsgebiet des Olt/Alt Flusses).

ADONIS: CE wurde zur Entwicklung eines spezifisches Managementmodells für die Populationen von Sabanejewia aurata (De Filippi, 1863) verwendet. Das vorgeschlagene Modell stützt sich auf die biologisch/ökologischen Anforderungen dieser in situ festgestellten Art in Beziehung zu den Habitaten, Indikatoren des Erhaltungszustandes sowie die entsprechenden Managementmaßnahmen aber auch zu den Gefahren und Bedrohungen der Art im Untersuchungsgebiet. Dieses auf die Art, ihre Lebensräume und das Gesamtgebiet bezogene Managementsystem wurde zur Vervollständigung dieser Herangehensweise für das Natura 2000 Gebiet ausgearbeitet. Die anderen in dem Gebiet lebenden Fischarten von naturschutzfachlicher Bedeutung wurden von diesem Gesichtspunkt aus bereits behandelt.

REZUMAT: Sistem suport decizional de management al populațiilor de Sabanejewia aurata (De Filippi, 1863) pentru ROSCI0132 (bazinul râului Olt).

ADONIS: CE a fost utilizat pentru a proiecta un model de management specific pentru populaţiile de Sabanejewia aurata (De Filippi, 1863). Modelul propus se bazează pe necesităţile biologice/ecologice ale acestei specii identificate in situ în relaţie cu habitatele, indicatorii stării de conservare şi acţiunile adecvate de management, şi cu presiunile şi ameninţările identificate în aria studiată. Acest sistem de management bazat pe specie, habitate şi sit a fost realizat pentru completarea acestei abordări pentru ROSCI0132, celelalte specii de peşti de interes conservativ care trăiesc acolo au fost deja tratate din acest punct de vedere. 


\section{INTRODUCTION}

With the concern of ensuring the survival of the vulnerable species of Europe, the European Union countries governments established an agreement with the Habitats Directive in 1992. Based on this international agreement, all these countries must ensure that the needed circumstances are met, for the conservation of the species and habitats included in Directive (Annex 2), along with the ultimate goal to protect and if is possible to increase their ecological status. The admission of Natura 2000 sites propositions depend on explicit criteria like the following: stable, unspoiled and healthful fish populations, advantageous geographic location, characteristic natural habitats and minor anthropogenic impact. There are some distinct directions through which the EU Natura 2000 network strategy intends to improve the member countries' nature quality like: the expanding of the natural areas space; boosting information; institutional capacity construction; proper field assessment; integrated monitoring and appropriate management actions in integrated management plans for the protected areas. (Bănăduc, 2007; Bănăduc et al., 2012)

Sabanejewia aurata (De Filippi, 1863) is a fish species of Community interest. It is a freshwater and demersal species, appearing commonly in the upper and middle sectors of the lotic systems. The existence of the sand substrata is an essential habitat characteristic. The food of this species consists of small macroinvertebrates. (Bănărescu, 1964; Bănărescu and Bănăduc, 2007)

The structure of the fish communities, where Sabanejewia aurata species is found, in Oltul Mijlociu-Cibin-Hârtibaciu Natura 2000 site (ROSCI0132) calls attention to relatively decreasing individual numbers as a result of the anthropogenic impact. The discontinuity on the area of this fish species and their relatively low abundance demonstrates the Olt Basin aquatic habitat's diminishing quality (Bănăduc, 1999, 2000; Curtean-Bănăduc and Bănăduc 2001, 2004; Curtean et al., 1999; Curtean-Bănăduc et al., 2007).

In the contemporary universal shift the lotic systems becomes more incalculable natural capital, the anthropogenic stress on it will reduce the human society use of it (CurteanBănăduc and Bănăduc, 2012).

If this trend will advance, any general management plan will not be adequate in dissimilar protected natural areas, as a matter of fact numerous and diverse habitat components should be initially investigated. As well, the adapted management aspects have to tailor and advocate the local habitats/species discrete situation.

Recently, the components of the modelling process are used more to obtain an "extensive image" of individual systems and/or actions of distinct spheres. The components of the process are helpful in discerning the process phases for a pragmatic and practical management. Essentially the modelling means are expressed by software products, which are used to design models of work organizations, and to expose data about the models. There are three major operations: confirm the current state, evaluate the consequences of potential modifications and recommend a program to adjust the current state in a needed way. Finally are proposed diverse methods to create diagrams which reveal particular management components (Hall and Harmon, 2005).

This study's goals are: to underline the current state of the populations of Sabanejewia aurata in ROSCI0132 area; to illustrate the present anthropogenic threats and pressures; and to recommend through management proposals the recovery of the fish species' conservation status based on a expressly designated model of management - which combine habitat preconditions of the fish species and habitat indicators as a decisional management system. 


\section{MATERIAL AND METHODS}

The Natura 2000 site ROSCI0132 is located in the Romanian administrative areas (județe/counties) Sibiu, Braşov and Vâlcea (45.682778 latitude, 24.324444 longitude, 2826.10 ha surface, 314 and 568 a.s.l. m). This protected area is positioned in the Continental and Alpine European bio-geographic zones. It was proposed to include ten species of fish of conservative interest-species listed in the Annex 2 of the Habitats Directive (92/43/EEC), (Sabanejewia aurata De Filippi, 1863 - Natura 2000 code 1146, Cobitis taenia, Barbus meridionalis, Pelecus cultratus, Zingel zingel, Zingel streber, Rhodeus amarus, Aspius aspius, Romanogobio kesslerii and Romanogobio uranoscopus).

The river sectors of the researched zone where the species Sabanejewia aurata was found are shown in figure 1.

The Sabanejewia aurata individuals were sampled in 2010-2013, with fishing nets, identified and freed in their habitat.

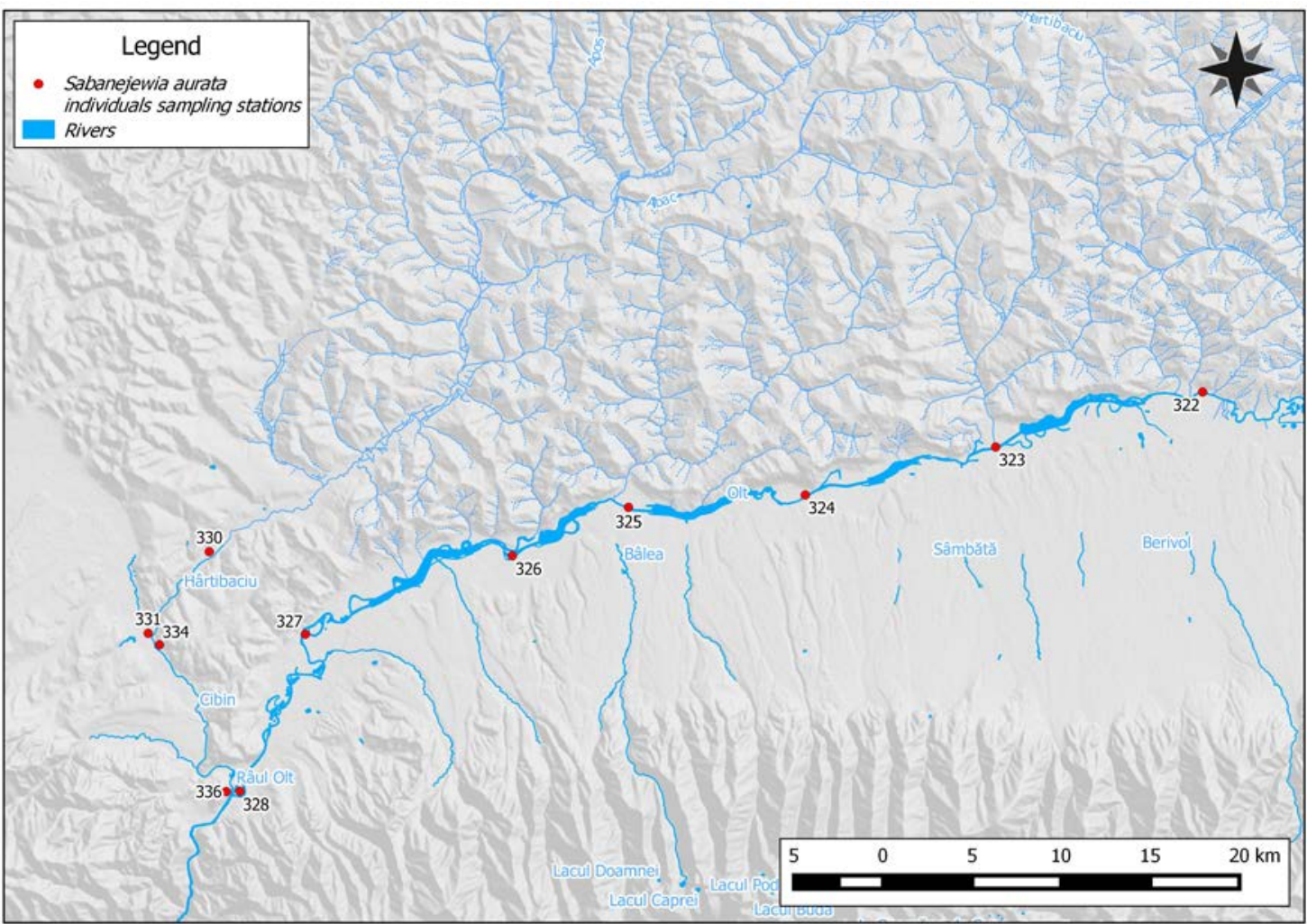

Figure 1: Sabanejewia aurata individuals sampling stations in: Cibin River (334 and 336),

Hârtibaciu River (330 and 331) and Olt River (322, 323, 324, 325, 326, 327, 328)

(Geographic Information System support Mr. Pătrulescu A.).

Sabanejewia aurata populations were under evaluation during this study period and their ecological condition was assessed in connection to the local anthropogenic pressures and threats on this species' habitats and populations. 
The ecological condition of the fish population was assessed based on certain criteria: size of the area dispersal, balanced distribution of fish on age classes, population size and a high/low number of fish species individuals in the local communities.

The Sabanejewia aurata fish species habitat necessities, pressures, and threats were studied in relation with their status of existence, and the dependence between them and the fish conservation condition.

An adjusted management model was proposed in order to set up the proper management components that are anticipated to help in protecting the fish species that are present in the study area, in addition to emphasize the necessary process. For that reason, ADONIS:CE was tested, created by Business Object Consulting. ADONIS: Community Edition, a charge-less tool provided by the BOC Group, which can be use in taking efficient action as a point of access to Business Process Management. ADONIS:CE is an easy, standalone form of ADONIS with some constraints (in contrast with the commercial edition). Business Process Model and Notation (BPMN) is a standard modelling terminology which helps to bring light to particular processes. These processes can be modelled depending on consistent notation.

\section{RESULTS AND DISCUSSION}

Sabanejewia aurata populations ecological state assessment elements

The conservation state of Sabanejewia aurata in the Olt River sampling sectors (322, 323, 324, 325, 326, 327, and 328) (Fig. 1) can be classified as good in 322, 324, 325, 326 and 328 and low in 323 and 327 in the general background of: balanced distribution of fish individuals on age classes, population sizes, and an average percentage of individuals of this fish species in the local fish fauna structure. The aquatic habitats of the researched area fish communities are in an average conservation state, regarding the Sabanejewia aurata ecological necessities.

The conservation status of Sabanejewia aurata in the Cibin River sampling sectors (334 and 336) (Fig. 1) can be considered as good in 336 and low in 334. These aquatic habitats are in an average conservation state, in respect of Sabanejewia aurata ecological necessities.

The conservation state of Sabanejewia aurata fish species in the Hârtibaciu River sampling sectors (330 and 331) (Fig. 1) can be considered as good. The researched habitats are in an average state of conservation, in respect of Sabanejewia aurata ecological necessities.

\section{Human pressures and threats}

Research show that, the main pressure on Sabanejewia aurata species is water pollution. The identified threats are: water pollution, riverine lands erosion and the accentuated presence of mud in the riverbed as a result of the bad agricultural practices in the basin, the destruction of the riverine vegetation and/or the illegal waste dumps in the rivers' proximity. This can negatively affect this species trophic base and its necessary substrata for reproduction.

For the reason that the sectors that have appropriate environment conditions are decreasing due to anthropogenic impact, all the river sectors which presently provide good habitats are essential for this fish species' conservation status; and the destruction of these good habitats causes overpopulation, the creation of conditions for parasites, infections, illnesses and invasive fish species, and later the diminishing of the individuals' number. 


\section{Specific requirements}

Generally, this species needs river sectors with relatively average water speed flow, a substrate that is formed of sand mixed with pebbles or pure sand and ligneous riparian vegetation. The reproduction occurs between May and July. Both the adults and juveniles are sensitive to pollution. (Bănărescu, 1964; Bănărescu and Bănăduc, 2007)

\section{Specific habitat indicators}

In the context of the Sabanejewia aurata presence/absence and abundance in the studied sectors, some habitat indicators are recommended: average speed flowing water surface percentages (50\%), mixed sandy-pebbles (33\%) or sandy substratum surface percentages (33\%), river banks with riparian vegetation percentages (50\%).

\section{Management measures}

The main management measures in this case are: keeping the natural morphology of the riverbed and banks, prohibit the abandonment of any kind of waste in the riverbed and surrounding wetlands of watercourses, implementation of an integrated monitoring system for ichtyofauna conducted by qualified/specialised personal.

\section{Site adjusted management model}

The onsite designated Sabanejewia aurata management model proposes a scheme of the species and the conditions which provide in with a good conservation status.

As a matter of fact, we modelled the ecological needs of the Sabanejewia aurata species applying the ADONIS:CE (Hall and Harmond, 2005) modelling tool and the elements are: activities $(\square)$, decisions $(\diamond)$, subprocesses $(\Delta)$, variables $(\bullet)$ and generators $(\bullet)$. The flow logic is displayed through the insertion of connectors, specifically through the relation "Subsequent" $(\longrightarrow)$. Through this relation, which joins any object with the next object, the logical flow of this specific model can be identified (ADONIS:CE Help).

Figure 2 shows how management model is organised using two business process model (BPM): Sabanejewia aurata 1 - which is the main model process and Indicators and management measures 1 - which is a subprocess included in the basic process model.

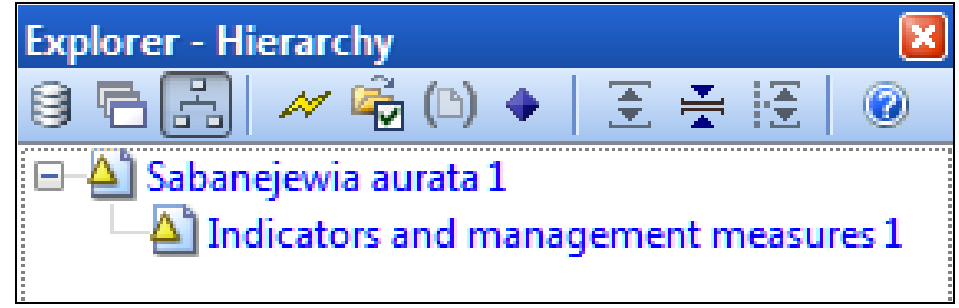

Figure 2: Sabanejewia aurata hierarchy models.

The basic process ( $\triangle$ is set of activities, subprocesses, decisions to be followed in order) presents the ecological requirements fact sheet of the species and is named Sabanejewia aurata 1 (Fig. 3). The objects used to model this process are: six activities (ロ) presents the steps of a process and fields as description, comments; can also be attached via supporting documents to certain activity, one subprocess ( $\Delta$ allows sub-structuring for easy browsing) and one decision ( $\diamond$ forms of verification) with variable and generator ( $\theta$ ) variable represents the indicator name and through generator (๑). We assigned the percentage, obtained on the field during measurements, for an indicator that ensures favourable preservation status. 
The first three activities describe the habitat characteristics, its specific requirements and also the field observations. Following the subprocess "Indicators and management measures" where possible indicators are browsing from one to another to see if the percentage obtained on the ground is the same one that provides a favourable conservation status, and also what management measures are to be taken. The main process continues with the decision "The conservation state is favourable?", that verifies whether or not the species is in favourable conservation status. If it goes on "Yes" branch ("Conservation_state = Yes", Probability $=\mathbf{9 9 \%}$ ), the process continues with three activities which present additional characteristics of the species (other ecological requirements, which is the breeding period, highlighting the main pressures and threats of the species) and the process is completed ( ). If the species does not meet the condition of being in favourable conservation status (the "No" branch - "Conservation_state $=$ No", Probability $=1 \%$ ), then returns to activity Specific requirements and repeat until the species has a favourable conservation status (our aim is to preserve the species).

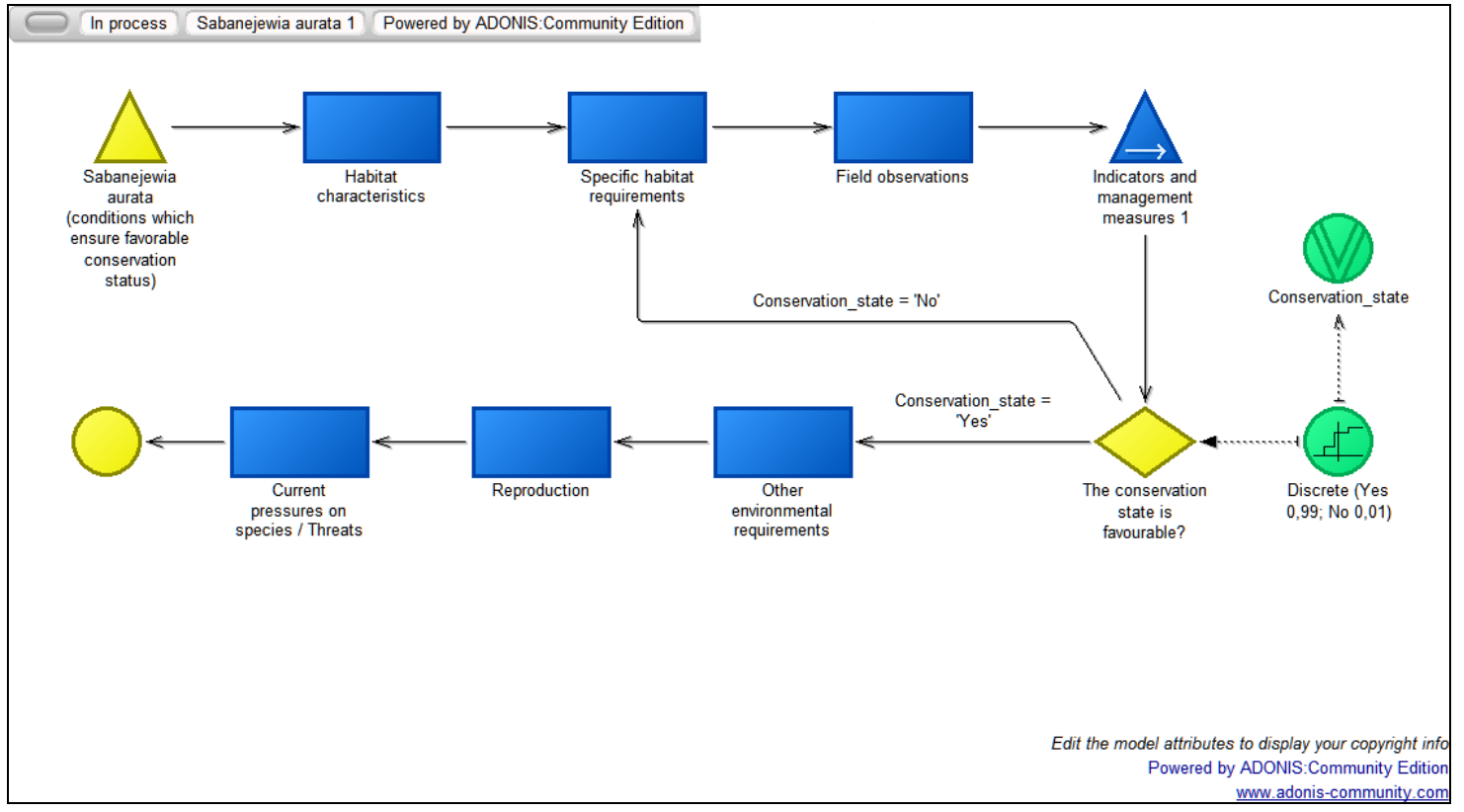

Figure 3: Sabanejewia aurata - main process.

As mentioned earlier, the second process modelled is subprocess Indicators and management measures for Sabanejewia aurata species (Fig. 4) and is called from basic Sabanejewia aurata model process. The subprocess has the same characteristics as a process in which it is checked if possible indicators (measured on the ground) ensure favourable conservation status of the species.

The subprocess was modelled using four decisions (possible indicators measured) and three activities that represent the management measures to be taken to ensure the species conservation. For each decision we have a variable and a generator. 
Each generator was assigned the percentage for each indicator that ensures the favourable conservation status. As a result of the decision, if it goes on the "Yes" branch (e.g.: "The actual state of sandy substrate weight is 33\%?, Sandy_substrate = Yes", Probability = $90 \%$ or "The actual state of average water speed flow is 50\%?", Water_speed_flow = "Yes", Probability $=80 \%$ ), then proceed to the next decision/indicator. If the percentage does not fit into the standards of conservation (e.g.: "The actual state of sandy substrate weight is $33 \%$ ?", Sandy_substrate $=$ "No", Probability $=10 \%$ or "The actual state of average water speed flow is $50 \%$ ?", Water_speed_flow $=$ "No", Probability $=20 \%$ ), using the parallelism $(\triangleleft)$ and merging $(\triangleright)$ are presented the management measures that are to be taken to ensure the wellbeing/welfare of the species: keeping natural morphodynamics of riverbeds, prohibit the abandonment of any kind of waste in the river bed and wetlands surrounding watercourses. The process finishes with the activity implementation of an integrated monitoring system for ichtyofauna performed by qualified/specialized staff (which is also a measure of management).

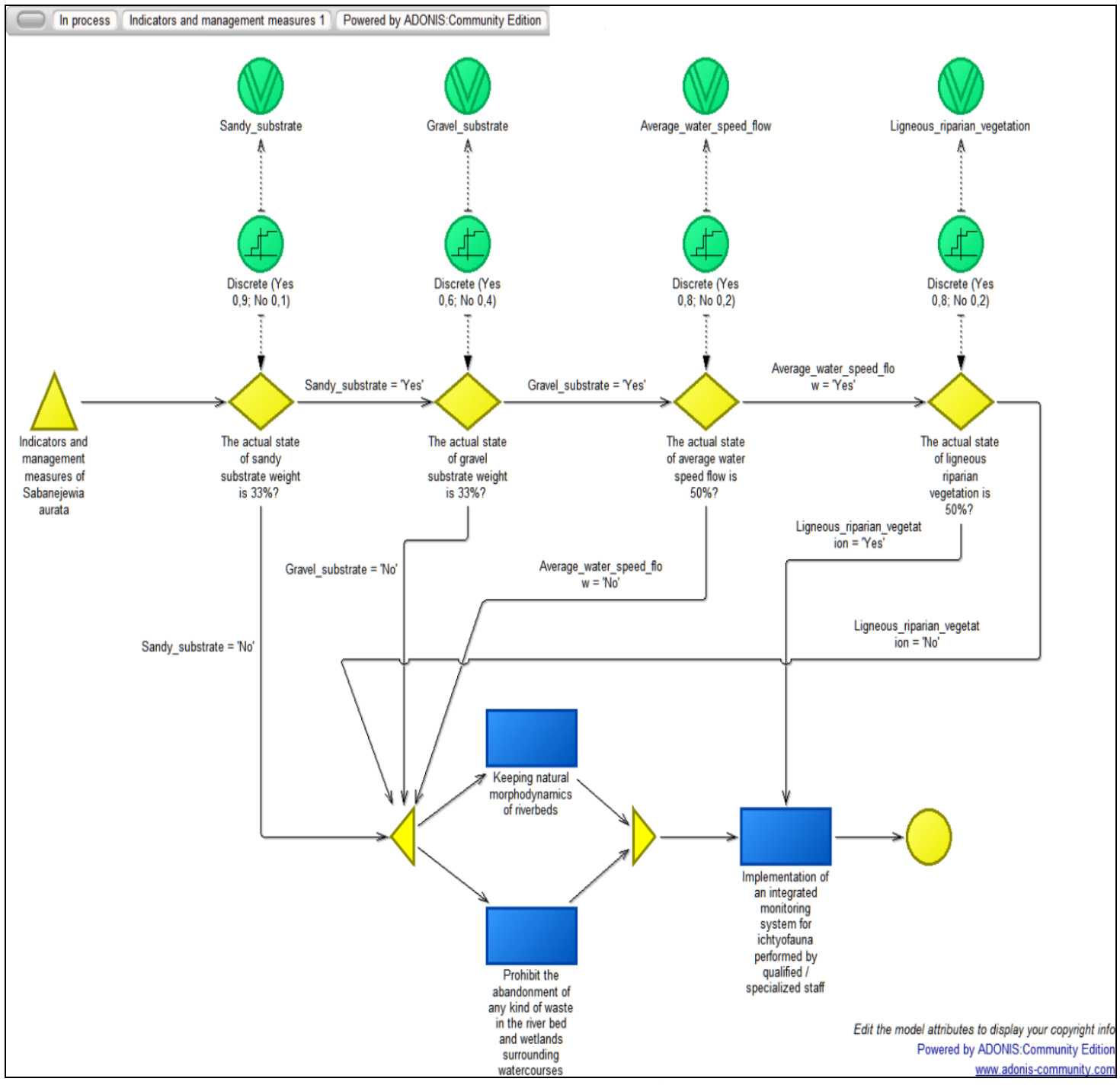

Figure 4: Indicators and management measures for Sabanejewia aurata species. 


\section{CONCLUSIONS}

In order to have a favorable conservation status in ROSCI0132 Natura 2000 site for Sabanejewia aurata the principal identified threats to this fish species are: water pollution, riverine land erosion and riverbed over silting with mud. The identified pressure was the water pollution.

Important issues that need to be addressed for the Sabanejewia aurata fish species conservation are: preservation the natural morphology of the riverbed and banks, ban the abandonment of waste in the riverbed and neighboring wetlands of rivers, creation of an integrated monitoring system for fish fauna coordinated by competent persons.

In this research, an indispensable management model in order to back the Sabanejewia aurata populations in a specific site (ROSCI0132 Natura 2000 site) was created.

The ADONIS:CE was used in this research in the nature concervation context, indicating a management model of Sabanejewia aurata that enclose its most important needs in relation to the habitat, the indicators that describe a favorable ecological status - the appropriate management to avoid and/or eliminate the pressures and threats which distress this fish species populations.

If the proposed management aspects will be not implemented, Sabanejewia aurata will have a decreasing conservation status in the next 10-20 years in the researched area.

This specific on-site, on-habitats and on-species management elements sustaining model for Sabanejewia aurata, should be incorporated in an integrate management model for the ROSCI0132 site ichthyofauna. 


\section{ACKNOWLEDGEMENTS}

This study information was in some measure obtained in the research period for POS Mediu, priority ax 4 project code SMIS - CSNR 17049 "Pentru Comunităţi Locale şi Natură - Bazele managementului integrat Natura 2000 în zona Hârtibaciu - Târnava Mare - Olt (PH+ PRO MANAGEMENT Natura 2000)”. 


\section{REFERENCES}

1. Bănăduc D., 1999 - Data concerning the human impact on the ichthyofauna of the upper and middle sectors of the Olt River, Transylvanian Review of Systematical and Ecological Research, 1, Edit. Universităţii “Lucian Blaga” din Sibiu, ISSN 1841-7051, ISBN 973-9410-69-3, 157164.

2. Bănăduc D., 2000 - Ichthyofaunistic criteria for Cibin River human impact assessment, Travaux du Museum National d’Histoire Naturelle Grigore Antipa, București, XLII, 365-372.

3. Bănăduc D., 2007 - Middle Olt River (Transylvania, Romania) - Special area for conservation (Natura 2000 Site) proposal for Cobitis taenia Risso, 1827 and associated fish species, Acta Ichtiologica Romanica, II, 37-42.

4. Bănăduc D., Nagy A. and Curtean-Bănăduc A., 2012 - New SCIS proposal regarding the ichthyofauna after the Continental Biogeographic Seminar for Romania, Sibiu (Transylvania, Romania), 9-12 June 2008, Acta Oecologica Carpatica, V, 145-158.

5. Bănărescu P. M., 1964 - Pisces-Osteichthyes, Fauna R. P. România, XIII, Edit. Academiei R. P. România, Bucureşti, 959.

6. Bănărescu P. M. and Bănăduc D., 2007 - Habitats Directive (92/43/EEC) fish species (Osteichthyes) on the Romanian Territory, Acta Ichtiologica Romanica, II, 43-78.

7. Curtean-Bănăduc A. and Bănăduc D., 2001 - Cibin River (Transylvania, Romania) management, scientific foundation proposal, Acta Oecologica, VIII, 1-2, Edit. Universităţii „Lucian Blaga” din Sibiu, ISSN 1221-5015, 85-100.

8. Curtean-Bănăduc A. and Bănăduc D., 2004 - Aspecte privind dinamica faunei râului Cibin în ultimii 150 de ani, Studii şi Comunicări, Muzeul de Ştiinţele Naturii din Sibiu, 29, ISSN 14544784, 205-214. (in Romanian)

9. Curtean-Bănăduc A., Bănăduc D. and Bucşa C., 2007 - Watershed Management (Transylvania, Romania) - implications, risks, solutions, Strategies to Enhance Environmental Security in Transition Countries, NATO Security trough Science Series - C: Environmental Security, Springer, 225-238, ISBN 978-1-4020-5995-7.

10. Curtean-Bănăduc A. and Bănăduc D., 2012 - Aspecte privind impactul deversării apelor uzate asupra sistemelor ecologice lotice receptoare, Apa resursă fundamentală a dezvoltării durabile, Metode şi tehnici neconvenţionale de epurare şi tratare a apei, II, coordonator Oprean L., Edit. Academiei Române, 393-416. (in Romanian)

11. Curtean A., Sîrbu I., Drăgulescu C. and Bănăduc D., 1999 - Impactul antropic asupra biodiversităţii zonelor umede din bazinul superior şi mijlociu al Oltului, Edit. Universităţii „Lucian Blaga” din Sibiu, ISBN 973-651-003-4, 102. (in Romanian)

12. Hall C. and Harmon P., 2005 - The Enterprise Architecture, Process Modeling and Simulation Tools Report, Version $1.1 \quad$ (2005) November, 2005, http://mhcnet.com/whitepapers_presentations/2005, Process Trends (040306).pdf 